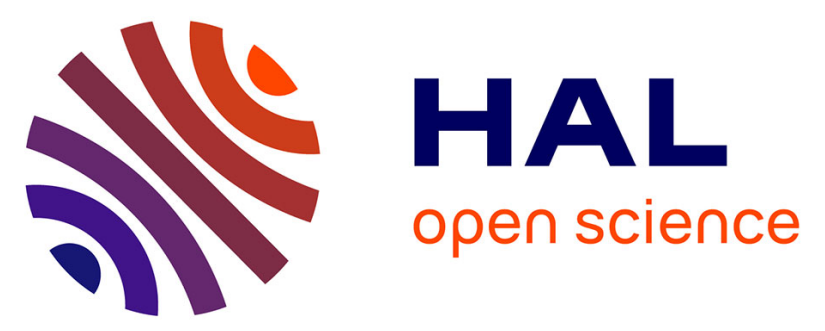

\title{
Genome size diversity in stingless bees (Hymenoptera: Apidae, Meliponini)
}

Mara Tavares, Carlos Carvalho, Fernanda Soares, Lucio Oliveira Campos

\section{To cite this version:}

Mara Tavares, Carlos Carvalho, Fernanda Soares, Lucio Oliveira Campos. Genome size diversity in stingless bees (Hymenoptera: Apidae, Meliponini). Apidologie, 2012, 43 (6), pp.731-736. 10.1007/s13592-012-0145-x . hal-01003667

\section{HAL Id: hal-01003667 https://hal.science/hal-01003667}

Submitted on 1 Jan 2012

HAL is a multi-disciplinary open access archive for the deposit and dissemination of scientific research documents, whether they are published or not. The documents may come from teaching and research institutions in France or abroad, or from public or private research centers.
L'archive ouverte pluridisciplinaire HAL, est destinée au dépôt et à la diffusion de documents scientifiques de niveau recherche, publiés ou non, émanant des établissements d'enseignement et de recherche français ou étrangers, des laboratoires publics ou privés. 


\title{
Genome size diversity in stingless bees (Hymenoptera: Apidae, Meliponini)
}

\author{
Mara Garcia Tavares, Carlos Roberto Carvalho, \\ Fernanda Aparecida Ferrari Soares, Lucio Antonio de Oliveira Campos \\ Departamento de Biologia Geral, Universidade Federal de Viçosa, Av. P H Rolfs, s/n , CEP: 36.570-000, Viçosa, \\ Minas Gerais, Brazil
}

Received 10 March 2012 - Revised 8 May 2012 - Accepted 23 May 2012

\begin{abstract}
The first studies on the genome size of stingless bee species showed a range from $0.27 \mathrm{pg}$ (Melipona subnitida and Melipona quadrifasciata) to $1.38 \mathrm{pg}$ (Melipona capixaba). Considering this variation, we quantified the DNA content of 26 species of Meliponini, in order to provide input for future comparative studies in this tribe. Haploid genome size (1C) estimates, using flow cytometry analyses (FCM), ranged from $0.26 \pm 0.003 \mathrm{pg}$ (Paratrigona subnuda) to $0.98 \pm 0.023 \mathrm{pg}$ (Melipona flavolineata), with an average of $0.54 \pm 0.17 \mathrm{pg}$. FCM analyses also demonstrated a small difference in the haploid genome size between males and females of the same species, with the males generally having a smaller genome than females. Our data also evidenciated that variations in the genome size of stingless bees do not correlate with changes in chromosome number and that in some genera the DNA content is more variable than in others.
\end{abstract}

C-value / DNA content / flow cytometry / meliponines

\section{INTRODUCTION}

The stingless bees (Meliponini) exhibit a pantropical distribution, covering most of the Neotropical regions. More than 500 species and 50 genera have been described, with more than 300 species being found in Central and South America (Michener, 2000).

The stingless bees differ from other bees by particular characteristics such as atrophy of the sting and reduced wing venation (Michener, 2000). They also are distinguished by their great diversity of social behavior and its important role in pollinating of native species.

The first studies on the genome size of these species have been published recently by Lopes et al. (2009) and Tavares et al. (2010a, b). In

Corresponding author: M.G. Tavares,

mtavares@ufv.br

Manuscript editor: David Tarpy total, the genome size of 19 stingless bee species was estimated, most of them belonging to the genus Melipona. At the same time, the genomes of 89 other Hymenoptera species were quantified (Ardila-Garcia et al., 2010). These studies helped to expand the genome size Hymenoptera dataset, which until then had data for only 50 species.

Together, these results showed a range in the haploid genome size (1C) of Hymenoptera from $0.10 \mathrm{pg}$ (Aphidius colemani) to $1.38 \mathrm{pg}$ (Melipona capixaba). Considering this variation it is evident that additional information can provide important data on the evolution of genome size of this order and their associations with rates of development, body size, and levels of sociality. Genome size determination can also guide the choice of genomes to be sequenced (Hardie et al., 2002; Gregory, 2005; Geraci et al., 2007). The aim of this study therefore was to quantify the genome size of 26 species of Meliponini, in order to 
provide input for future comparative studies in this tribe and in the order Hymenoptera.

\section{MATERIALS AND METHODS}

\subsection{Biological material}

The present study analyzed 26 species of stingless bees, belonging to 15 genera. This material was kindly provided by researchers from different educational institutions or bee keepers that sent us combs containing individuals at different developmental stages. Species were identified by Dr. Lucio Antonio de Oliveira Campos (Universidade Federal de Viçosa-UFV).

\subsection{Flow cytometry analysis}

The flow cytometry (FCM) analyses were carried out at the Laboratory of Cytogenetics and Cytometry, Department of General Biology, UFV. Analyses were performed using the cerebral ganglion of female pupae. In a complementary way, male pupae in the same stage of development were analyzed when present in the combs. Melipona quadrifasciata diploid males (see Table I) were obtained from inbred colonies originated from a brother-sister mating and identified by cytogenetic analysis according to Imai et al. (1988).

The nuclear DNA content of pupae was measured using as internal standard the C DNA content value of a female of Scaptotrigona xantotricha as described by Lopes et al. (2009). For preparation of FCM nuclei suspensions, brain ganglion nuclei of the standard and sample were excised in physiologic solution $(0.155 \mathrm{mM} \mathrm{NaCl})$. The materials were simultaneously crushed 10 times with a pestle in a tissue grinder (Kontes Glass Company ${ }^{\circledR}$ ) with $100 \mu \mathrm{L}$ OTTO-I lysis buffer (Otto, 1990) containing $0.1 \mathrm{M}$ citric acid $\left(\operatorname{Merck}^{\circledR}\right), \quad 0.5 \%$ Tween $20 \quad\left(\operatorname{Merck}^{\circledR}\right)$, and $50 \mu \mathrm{g} \mathrm{mL}^{-1}$ RNAse (Sigma-Aldrich ${ }^{\circledR}$ ), $\mathrm{pH}=2.3$. The suspension was adjusted to $1.0 \mathrm{~mL}$ with the same buffer, filtered through $30 \mu \mathrm{m}$ nylon mesh $\left(\operatorname{Partec}^{\circledR}\right.$ ) and centrifuged at $100 \times g$ in microcentrifuge tubes for $5 \mathrm{~min}$. The pellet was then incubated for $10 \mathrm{~min}$ in $100 \mu \mathrm{L}$ OTTO-I lysis 100 buffer and stained with $1.5 \mathrm{~mL}$ OTTO-I:OTTO-II (1:2) solution (30 min; Loureiro et al., 2006a, b) supplemented with $75 \mu \mathrm{M}$ propidium iodide (PI Sigma ${ }^{\circledR}$ —excitation/emission wavelengths, 480-575/550-740 nm; Shapiro, 2003) and $50 \mu \mathrm{g} \mathrm{mL}^{-1}$ RNAse (Sigma-Aldrich ${ }^{\circledR}$ ), $\mathrm{pH}=7.8$. The nuclear suspension was filtered through $20 \mu \mathrm{m}$ diameter mesh nylon filter $\left(\operatorname{Partec}^{\circledR}\right)$ and maintained in the dark for 5-40 min. The suspension was analyzed with a Partec PAS ${ }^{\circledR}$ flow cytometer (Partec $\left.{ }^{\circledR}\right)$ equipped with a Laser source $(488 \mathrm{~nm})$. The equipment was calibrated for linearity and aligned with microbeads and standard solutions according to the manufacturer's recommendations. FlowMax ${ }^{\circledR}$ software $\left(\right.$ Partec $\left.^{\circledR}\right)$ was used for data analyses. Three independent replications were done, and histograms with coefficient of variation above $5 \%$ were rejected.

The mean genome size (in picograms) of each sample was measured according to the formula adapted from Dolezel and Bartos (2005) and will be presented here as $\mathrm{C}$-values in picograms and megabase pairs (1 pg=978 Mbp; Dolezel et al., 2003). A standard Student's $t$ test $(P<0.05)$, as implemented in the GENES program (Cruz, 2011), was used to determine significant differences in genome size between sexes, for the 20 species for which it was possible to obtain estimates of genome size for both sexes (Table I).

\section{RESULTS}

Genome size (1C) estimates for the analyzed females ranged from $0.26 \pm 0.003 \mathrm{pg}$ (Paratrigona subnuda) to $0.98 \pm 0.023 \mathrm{pg}$ (Melipona flavolineata), with an average of $0.54 \pm 0.17 \mathrm{pg}$ (Table I). Analyses also showed that the genome size of haploid males was slightly smaller than the $1 \mathrm{C}$ content of diploid females (Table I). The results of the $t$ standard test showed statistically significant differences $(P<0.05)$ for Celetrigona longicornis, Scaptotrigona bipunctata, Nanotrigona testaceicornis, Partamona rustica, Melipona mondury, Melipona quinquefasciata, Melipona asilvai, and Melipona mandacaia. Diploid males of M. quadrifasciata, however, presented exactly the same genome size of females. Variations in the genome size of Frieseomelita varia and Plebeia droryana according to their geographical origins were also observed. Samples of $F$. varia from Ribeirão Preto and Bocaiúva, for instance, showed genome sizes of $0.46 \pm 0.000$ and $0.48 \pm 0.004 \mathrm{pg}$, respectively, while the genome size of $P$. droryana samples 
Table 1. Haploid genome size estimates for 26 stingless bee species, their origin, number of individuals analyzed $(\mathrm{N})$ and chromosome number.

\begin{tabular}{|c|c|c|c|c|c|}
\hline \multirow[t]{2}{*}{ Species } & \multirow[t]{2}{*}{ Origin } & \multicolumn{2}{|c|}{ Haploid genome size $(\mathrm{pg}) \pm \mathrm{SE}(\mathrm{Mbp})$} & \multirow[t]{2}{*}{$N$} & \multirow{2}{*}{$\begin{array}{l}\text { Chromosome } \\
\text { number }\end{array}$} \\
\hline & & Female & Male & & \\
\hline Friesella schrottkyi & Pedregulho/SP & $0.44 \pm 0.007(430.32)$ & $0.42 \pm 0.005(410.76)$ & 3 & $2 n=34^{\mathrm{a}}$ \\
\hline Frieseomelita varia & Ribeirão Preto/SP & $0.46 \pm 0.000(449.88)$ & - & 3 & $2 n=30^{\mathrm{a}}$ \\
\hline F. varia & Bocaiúva/MG & $0.48 \pm 0.004(469.44)$ & $0.47 \pm 0.005$ & 3 & $2 n=30^{\mathrm{a}}$ \\
\hline Frieseomelita sp. & Jequié/BA & $0.44 \pm 0.006(430.32)$ & - & 3 & ND \\
\hline Celetrigona longicornis & Nova Xavantina/AC & $0.49 \pm 0.004(479.22)$ & $0.46 \pm 0.005(449.88)$ & 3 & $n=15^{\mathrm{a}}$ \\
\hline Cephalotrigona sp. & Urbano Santos/MA & $0.55 \pm 0.007(537.90)$ & - & 3 & ND \\
\hline Scaptotrigona bipunctata & Ribeirão Preto/SP & $0.44 \pm 0.005$ & $0.40 \pm 0.010(391.20)$ & 3 & ND \\
\hline S. depilis & Ribeirão Preto/SP & $0.41 \pm 0.008(400.98)$ & $0.39 \pm 0.008(381.42)$ & 3 & $2 n=34^{\mathrm{a}}$ \\
\hline S. tubiba & Urbano Santos/MA & $0.45 \pm 0.006(440.10)$ & - & 3 & ND \\
\hline S. xantotricha ${ }^{\text {b }}$ & Viçosa/MG & $0.44 \pm 0.004(430.3)$ & $0.42 \pm 0.005(410.76)$ & 3 & $2 n=34^{\mathrm{a}}$ \\
\hline Nanotrigona testaceicornis & Viçosa/MG & $0.53 \pm 0.009(518.34)$ & $0.49 \pm 0.004(479.22)$ & 3 & $2 n=34^{\mathrm{a}}$ \\
\hline Nanotrigona sp. & Xapuri/AC & $0.45 \pm 0.025(440.10)$ & - & 3 & ND \\
\hline Paratrigona subnuda & Viçosa/MG & $0.26 \pm 0.003(254.28)$ & - & 3 & $2 n=34^{\mathrm{a}}$ \\
\hline Trigona spinipes & Viçosa/MG & $0.44 \pm 0.010(430.32)$ & $0.42 \pm 0.007(410.76)$ & 3 & $2 n=34^{\mathrm{a}}$ \\
\hline T. fulviventris & Urbano Santos/MA & $0.70 \pm 0.013(684.60)$ & $0.68 \pm 0.012(665.04)$ & 3 & $2 n=32^{\mathrm{c}}$ \\
\hline T. pallens & Urbano Santos/MA & $0.81 \pm 0.027(792.18)$ & & 3 & $2 n=34^{\mathrm{d}}$ \\
\hline Plebeia droryana & Viçosa/MG & $0.49 \pm 0.009(479.22)$ & $0.48 \pm 0.008(469.44)$ & 3 & $2 n=34^{\mathrm{a}}$ \\
\hline P. droryana & Ribeirão Preto/SP & $0.52 \pm 0.007(508.56)$ & - & 3 & $2 n=34^{\mathrm{a}}$ \\
\hline P. lucii & Viçosa/MG & $0.43 \pm 0.003(420.54)$ & - & 3 & $2 n=34^{\mathrm{e}}$ \\
\hline Plebeia sp. & Xapuri/AC & $0.44 \pm 0.005(430.32)$ & $0.43 \pm 0.007(420.54)$ & 3 & ND \\
\hline Tetragonisca angustula & Viçosa/MG & $0.90 \pm 0.015(880.20)$ & - & 3 & $2 n=34^{\mathrm{a}}$ \\
\hline Partamona helleri & Viçosa/MG & $0.55 \pm 0.006(537.90)$ & - & 3 & $2 n=34^{\mathrm{a}}$ \\
\hline P. rustica & Januária/MG & $0.59 \pm 0.010(577.02)$ & $0.57 \pm 0.007(557.46)$ & 3 & $2 n=34^{\mathrm{f}}$ \\
\hline P. chapadicola & Urbano Santos/MA & $0.63 \pm 0.027(616.14)$ & - & 3 & $2 n=34^{\mathrm{g}}$ \\
\hline Scaura latitarsis & Ribeirão Preto/SP & $0.44 \pm 0.005(430.32)$ & $0.43 \pm 0.013(420.54)$ & 3 & $2 n=34^{\mathrm{a}}$ \\
\hline Schwarziana sp. & Domingos Martins/ES & $0.65 \pm 0.008(635.70)$ & - & 3 & ND \\
\hline Leurotrigona muelleri & Ribeirão Preto/SP & $0.32 \pm 0.003(312.96)$ & $0.31 \pm 0.007(303.18)$ & 3 & $2 n=16^{\mathrm{a}}$ \\
\hline Melipona fasciculata & Urbano Santos/MA & $0.82 \pm 0.005(801.96)$ & - & 3 & $2 n=18^{\mathrm{h}}$ \\
\hline M. flavolineata & Urbano Santos/MA & $0.98 \pm 0.023(958.44)$ & - & 3 & $2 n=18^{\mathrm{h}}$ \\
\hline M. mondury ${ }^{\mathrm{b}}$ & Itamarandiba/MG & $0.95 \pm 0.014(929.10)$ & $0.94 \pm 0.010$ & 3 & $2 n=18^{\mathrm{i}}$ \\
\hline M. quinquefasciata ${ }^{\text {b }}$ & $\mathrm{CE}$ & $0.70 \pm 0.011(684.60)$ & $0.67 \pm 0.011(655.26)$ & 3 & $2 n=20+\mathrm{Bs}^{\mathrm{a}}$ \\
\hline M. asilvai ${ }^{\mathrm{b}}$ & São João Sabugi/PB & $0.29 \pm 0.003(283.62)$ & $0.26 \pm 0.007(254.28)$ & 3 & $2 n=18^{\mathrm{a}}$ \\
\hline M. bicolor ${ }^{\mathrm{b}}$ & Viçosa/MG & $0.28 \pm 0.004(273.84)$ & $0.25 \pm 0.002(229.83)$ & 3 & $2 n=18^{\mathrm{a}}$ \\
\hline M. mandacaia ${ }^{\mathrm{b}}$ & Uauá/BA & $0.35 \pm 0.004(342.30)$ & $0.33 \pm 0.007(322.74)$ & 3 & $2 n=18^{\mathrm{a}}$ \\
\hline M. quadrifasciata ${ }^{\text {b }}$ & Viçosa/MG & $0.27 \pm 0.002(264.06)$ & $\begin{array}{l}0.25 \pm 0.003 \\
\quad(229.83-\text { male, } n) \\
\text { and } 0.27 \pm 0.005 \\
(264.06-\text { male }, 2 n)\end{array}$ & 3 & $2 n=18 ; n=9^{\mathrm{a}}$ \\
\hline
\end{tabular}

\footnotetext{
$N D$ not determined

${ }^{a}$ Revision in Rocha et al. (2003)

${ }^{b}$ Female DNA content estimated previously by Tavares et al. (2010a, b)

${ }^{c}$ Domingues et al. (2005)

${ }^{\mathrm{d}}$ Praça-Fontes et al. (2010)

${ }^{\mathrm{e}}$ Caixeiro (1998, referred as Plebeia sp2)

${ }^{\mathrm{f}}$ Fernandes et al. (2012) personal communication

${ }^{\mathrm{g}}$ Fernandes et al. (2009)

${ }^{\mathrm{h}}$ Lopes et al. (2011)

${ }^{i}$ Lopes et al. (2009)
} 
from Viçosa and Ribeirão Preto was $0.49 \pm 0.009$ and $0.52 \pm 0.007 \mathrm{pg}$, respectively (Table I).

The cytometry analyses also demonstrated that in some bee genera, the genome size is more variable than in others. However, there are no defined limits for genome size among genera (Table I).

\section{DISCUSSION}

The data obtained in the present study substantially extend knowledge about stingless bees' genome size. Their mean haploid genome size (0.54 pg \pm 0.17$)$ is within the range previously described for $S$. xantotricha (Lopes et al., 2009), 17 Melipona (Lopes et al., 2009; Tavares et al., 2010a), and one Lestrimelitta species (Tavares et al., 2010b). It should be noted, however, that when all the 45 stingless bees that have had their genome size estimated are analyzed together, their average genome size rises to $0.61 \pm 0.27 \mathrm{pg}$. The average genome size of stingless bees, therefore, varies about five times and is considerably higher than the average found for the other Apidae or other Hymenoptera non-Apidae analyzed so far $(0.40 \pm 0.18$ and $0.37 \pm 0.18 \mathrm{pg}$, respectively; Gregory, 2011). In any case, it remains within the limit of $2 \mathrm{pg}$ proposed for holometabolous insects (Gregory, 2002). However, considering the lower limit, other Paratrigona species need to have their genome size estimated in order to confirm if the small genome size of P. subnuda is an exception or a characteristic of the entire genus.

A possible explanation for this variation is the existence of some Melipona species with a high genome size (range $0.7-1.38$ pg; Tavares et al., 2010a). However, relatively large genomes are not unique to Melipona once Partamona chapadicola, Schwarziana sp., Trigona fulviventris, Trigona pallens, and Tetragonisca angustula also have genomes with more than $0.63 \mathrm{pg}$ (range $0.63-0.90 \mathrm{pg}$; Table I). Variations caused by different numbers of pseudogenes, transposons, intergenic sequences, introns, and microsatellites could also explain the differences found. Nevertheless, as the genome of any stingless bee has been complete- ly sequenced, such information is not yet available.

In this sense, our data indicate that M. quadrifasciata and $M$. bicolor (which have been widely studied from a biological standpoint), and Melipona subnitida, Melipona marginata, and $P$. subnuda are the stingless bee species best suited to have their genomes completely sequenced, once they have small genome sizes. Data on the genome organization of these species may be used in future studies on the organization and evolution of Hymenoptera genomes.

Male ganglion cerebral cells of eight stingless bee species demonstrated a smaller genome than the haploid genome size from females. Lopes et al. (2009) had already observed this when analyzing the genome size of males and females of S. xantotricha. Geraci et al. (2007) also observed significant differences between the genome size of males and females of the ticks Amblyomma americanum, Amblyomma cajannense, Amblyomma maculatum, and Dermacentor andersoni. In these cases, the differences were justified by the XX:XO sex determination system of these species. Additionally, in the first three species, the presence of a relatively large $\mathrm{X}$ chromosome compared to autosomes has already been detected. This explanation, however, does not seem to apply to stingless bees, where males are haploid and females are diploid. On the other hand, for some stingless bee species analyzed herein, the differences in the haploid genome size of males and females were not significant, as has been reported for Apis mellifera (Honeybee Genome Sequencing Consortium, 2006).

It is worth noting that, as expected, diploid males of $M$. quadrifasciata had exactly the same genome size than females of this species. This result, together with data from Lestrimelitta sp. (Tavares et al., 2010b), suggests that the technique of flow cytometry can be used to distinguish between haploid and diploid stingless bees males.

Variations in the genome size of stingless bees do not correlated with changes in chromosome number. For example, Leurotrigona muelleri has 0.32 pg of DNA and $2 n=16$ chromosomes, while 
the estimated genome of $P$. subnuda is $0.26 \mathrm{pg}$ and this species has $2 n=34$ chromosomes. Likewise, the genome size of 18 species of Melipona with $2 n=18$ chromosomes ranged from 0.27 to $1.38 \mathrm{pg}$ (Tavares et al., 2010a; this study). However, some species of stingless bees, such as Partamona helleri (Costa et al., 1992), M. quinquefasciata (Rocha, 2002), Melipona rufiventris (Lopes et al., 2008), and Partamona cupira (Marthe et al., 2010) may have B chromosomes and their presence can interfere in the estimation of genome size of species (unpublished data).

Although variations in the genome sizes according to the geographical origin of samples, as observed in the present study for F. varia and $P$. droryana, had already been observed in ants (Tsutsui et al., 2008, Ardila-Garcia et al., 2010), wasps, and bees (Ardila-Garcia et al., 2010), its causes are not clear. As discussed above, it can be correlated with differences in the amount of heterochromatin between populations. Thus, the FCM technique could be evidenciating interpopulation differences in the amount of heterochromatin in these species. The association of flow cytometry with cytogenetic techniques that permit monitor the condensation degree of chromosomes might show if this correlation is also observed in other stingless bees genera.

The FCM analysis also showed that, while the genomes size of Frieseomelita and Scaptotrigona showed little variation, the values found for the three species of the genus Trigona ranged from $0.44 \mathrm{pg}$ (T. spinipes) to $0.70 \mathrm{pg}$ (T. fulviventris) and $0.81 \mathrm{pg}$ (T. pallens). This high variation corroborates the phylogenetic relationships between these three species, because as evidenced in the analysis conducted by Rasmussen and Camargo (2008) and Rasmussen and Cameron (2010), T. spinipes and T. fulviventris/T. pallens are in different clades.

On the other hand, our results differ from the phylogenetic proposal of Rasmussen and Cameron (2010) in relation to the four subgenera of Melipona. Considering the genome size, it is possible to verify that Meliponal Eomelipona and Melikerria/Michmelia form two distinct groups. However, according to
Rasmussen and Cameron (2010), despite the four genera form a single clade, Eomelipona and Michmelia are the two closer subgenera.

In summary, the data obtained in this study indicate that the genome size of the stingless bees differs significantly between species. Therefore, in more detailed studies involving other genera, a greater number of species and species with different levels of sociality may reveal important features about the evolution of the genome of this group of insects and if there are precise limits between the genome sizes of different genera of stingless bees.

\section{ACKNOWLEDGMENTS}

We are grateful to Dr. Leonardo Lopes Bhering for his statistical assistance with GENES Program and to all researches and bee keepers that kindly provided the specimens analyzed. This work was supported by the Brazilian agency FAPEMIG (Process number: APQ 218 00564-08).

Diversité dans la taille du génome chez les abeilles sans aiguillon (Hymenoptera: Apidae, Meliponini)

Valeur C / contenu de l'ADN / cytométrie en flux / meliponines

Variation der Genomgrösse bei Stachellosen Bienen (Hymenoptera: Apidae, Meliponini)

\section{C-Wert / DNA-Gehalt / Durchflusszytometrie / Meliponinen}

\section{REFERENCES}

Ardila-Garcia, A.M., Umphrey, G.J., Gregory, T.R. (2010) An expansion of the genome size dataset for the insect order Hymenoptera, with a first test of parasitism and eusociality as possible constraints. Insec. Mol. Biol. 19, 337-346

Caixeiro, A.P.A. (1998) Caracterização citogenética da heterocromatina constitutiva e sua implicação na evolução do cariótipo de espécies do gênero Plebeia (Hymenoptera: Apinae: Meliponini). Dissertação de Mestrado. Universidade Federal de Viçosa, Viçosa. 70p

Costa, M.A., Pompolo, S.G., Campos, L.A.O. (1992) Supernumerary chromosomes in Partamona cupira 
(Hymenoptera, Apidae, Meliponinae). Rev. Bras. Genet. 15, 801-806

Cruz, C.D. (2011) Programa Genes: Aplicativo Computacional em Genética e Estatística. Versão Windows —2011. UFV, Viçosa

Dolezel, J., Bartos, J. (2005) Plant DNA flow cytometry and estimation of nuclear genome size. Ann. Bot. 95, 99-110

Dolezel, J., Bartos, J., Voglmayr, H., Greilhuber, J. (2003) Nuclear DNA content and genome size of trouts and human. Cytometry 51A, 127-128

Domingues, A.M.T., Waldschmidt, A.M., Andrade, S.E., Andrade-Souza, V., Alves, R.M.O., Silva Junior, J.C., Costa, M.A. (2005) Karyotype characterization of Trigona fulviventris Guérin, 1835 (Hymenoptera, Meliponini) by $\mathrm{C}$ banding and fluorochrome staining: report of a new chromosome number in the genus. Gen. Mol. Biol. 28, 390-393

Fernandes A., Sampaio W.M.S., Lazarotto A. (2009) Contribuição citogenética ao estudo do gênero Partamona, In: I BIOTA- Ciclo de Estudos de Biologia de Tangará da Serra, Tangará da Serra. Resumo Expandido-Biologia Celular e Genética

Geraci, N.S., Jonston, J.S., Robinson, J.P., Wikel, S.K., Hill, C.A. (2007) Variation in genome size of argasid and ixodid ticks. Insect Biochem. Mol. Biol. 37, 399-408

Gregory, T.R. (2002) Genome size and developmental complexity. Genetica 115, 131-146

Gregory, T.R. (2005) The C-value enigma in plants and animals: a review of parallels and an appeal for partnership. Ann. Bot. 95, 133-146

Gregory, T.R. (2011) Animal Genome Size Database, http:// www.genomesize.com (accessed on 10 July 2011).

Hardie, D.C., Gregory, T.R., Hebert, P.D.N. (2002) From pixels to picograms: a beginners' guide to genome quantification by Feulgen image analysis densitometry. J. Histochem. Cytochem. 50, 735-749

Honeybee Genome Sequencing Consortium (2006) Insights into social insects from the genome of the honeybee Apis mellifera. Nature 443, 931-949

Imai, H., Taylor, R.W., Crosland, M.W.J., Crozier, R.H. (1988) Modes of spontaneous evolution in ants with reference to the minimum interaction hypothesis. Jpn. J. Genet. 63, 159-185

Lopes, D.M., Pompolo, S.G., Campos, L.A.O., Tavares, M.G. (2008) Cytogenetic characterization of Melipona rufiventris Lepeletier 1836 and Melipona mondury Smith 1863 (Hymenoptera, Apidae) by C banding and fluorochromes staining. Genet. Mol. Biol. 31, 49-52

Lopes, D.M., Carvalho, C.R., Clarindo, W.R., Praça, M.M., Tavares, M.G. (2009) Genome size estimation of three stingless bee species (Hymenoptera, Meliponinae) by flow cytometry. Apidologie 40, 517-523

Lopes, D.M., Fernandes, A., Praça-Fontes, M.M., Werneck, H.D., Resende, H.C., Campos, L.A.D. (2011)
Cytogenetics of three Melipona species (Hymenoptera, Apidae, Meliponini). Sociobiology 58, 185194

Loureiro, J., Rodriguez, E., Dole el, J., Santos, C. (2006a) Comparison of four nuclear isolation buffers for plant DNA flow cytometry. Ann. Bot. 98, 679-689

Loureiro, J., Rodriguez, E., Dole el, J., Santos C. (2006b) Flow cytometric and microscopic analysis of the effect of tannic acid on plant nuclei and estimation of DNA content. Ann. Bot. 98, 515-527

Marthe, J.B., Pompolo, S.G., Campos, L.A.O., Salomão, T.M.F., Tavares, M.G. (2010) Cytogenetic characterization of Partamona cupira (Hymenoptera, Apidae) by fluorochromes. Gen. Mol. Biol. 33, 253-255

Michener, C.D. (2000) The bees of the world. The John Hopkins University Press, Baltimore. 913p

Otto, F.J. (1990) DAPI staining of fixed cells for highresolution flow cytometry of nuclear DNA. In: Darzynkiewiez, Z., Crissman, H.A., Robinson, J.P. (eds.), Methods in Cell Biology, vol 33, Academic Press, San Diego, pp.105-110

Praça-Fontes, M.M., Fernandes, A., Werneck H., Campos, L.A.O., Drummond, M., Lopes, D. M. (2010) Contribuição ao estudo citogenético de espécies do gênero Trigona (Hymenoptera: Apidae: Meliponini). In: Anais do IX Encontro sobre Abelhas. Ribeirão Preto

Rasmussen, C., Camargo, J.M.F. (2008) A molecular phylogeny and the evolution of nest architecture and behavior in Trigona s.s. (Hymenoptera: Apidae: Meliponini). Apidologie 39, 102-118

Rasmussen, C., Cameron, S.A. (2010) Global stingless bee phylogeny supports ancient divergence, vicariance, and long distance dispersal. Biol. J. Linnean Soc. 99, 206-232

Rocha, M.P. (2002) Análises citogenéticas em abelhas do gênero Melipona (Hymenoptera, Meliponinae). Universidade Estadual de Campinas, São Paulo. $84 \mathrm{p}$

Rocha, M.P., Pompolo, S.G., Campos, L.A.O. (2003) Citogenética da tribo Meliponini (Hymenoptera, Apidae). In: Melo, G.A.R., Santos, I.A. (eds.), Apoidea Neotropica. Homenagem aos 90 anos de Jesus Santiago Moure, UNESC, Santa Catarina, Brasil, pp. 311-320

Shapiro, H.M. (2003) Practical flow cytometry, 4th ed., John Wiley \& Sons, New Jersey. 736p

Tavares, M.G., Carvalho, C.R., Soares, F.A.F. (2010a) Genome size variation in Melipona species (Hymenoptera: Apidae) and sub-grouping by their DNA content. Apidologie 41, 636-642

Tavares, M.G., Carvalho, C.R., Soares, F.A.F., Fernandes, A. (2010b) Detection of diploid males in a natural colony of the cleptobiotic bee Lestrimelitta sp. (Hymenoptera, Apidae). Gen. Mol. Biol. 33, 491-493

Tsutsui, N.D., Suarez, A.V., Spagna, J.C., Johnston, J.S. (2008) The evolution of genome size in ants. BMC Evol. Biol. 8, 1-9 